\title{
Retention and the Kinetics of Uptake and Export of Foliage-applied, Labeled Boron by Apple, Pear, Prune, and Sweet Cherry Leaves
}

\author{
G.A. Picchioni \\ LA 71272 \\ S.A. Weinbaum and P.H. Brown \\ Department of Pomology, University of California, Davis, CA 95616-8683 \\ Additional index words. nutrient mobility, ${ }^{10} \mathrm{~B}$, fruit trees
}

Department of Agricultural Sciences, Technology and Education, Louisiana Tech University, Ruston,

\begin{abstract}
Leaf retention, uptake kinetics, total uptake (per unit leaf area), export kinetics, and the total export of foliageapplied, labeled B $\left({ }^{10} \mathrm{~B}\right.$-enriched boric acid) were determined for apple (Malus domestics Borkh.), pear (Pyrus communis L.), prune (Prunus domestics L.), and sweet cherry (P. avium L.). Foliar uptake of labeled B by shoot leaves was $88 \%$ to 96\% complete within 24 hours of application. More than $50 \%$ of the B retained on shoot leaf surfaces following application was absorbed and exported within 6 hours of application. Genotypic differences in shoot leaf surface characteristics among the species tested greatly influenced the amount of solution retained per unit leaf area. Leaf retention capacity was the primary determinant of the quantity of $B$ absorbed by and exported from shoot leaves following foliar application. On average, apple shoot leaves retained, absorbed, and exported at least twice as much labeled $B$ per unit leaf area as prune and pear shoot leaves and three to four times as much as sweet cherry shoot leaves. The sink demand of nearby, mature apples did not affect the export of labeled B when applied to adjacent spur leaves, but the fruit imported 16\% of their total $B$ from the applied solution during a 10-day period. Despite extensive documentation for the immobility of B accumulated by leaves naturally (e.g., from the soil), the B accumulated by leaves following foliage application was highly mobile in all four species tested.
\end{abstract}

Foliar B fertilization provides beneficial effects for a number of fruit crops. Increases in pollen germination rate (de Wet et al., 1989), fruit yield (Hanson, 1991a), fruit set (Batjer and Thompson, 1949), and fruit quality (Holevas and Biris, 1980) have occurred in response to foliar B applications made near the bloom period or during the growing season.

The extent of nutrient redistribution from treated leaves to target organs partly determines the effectiveness of foliar nutrient applications (Weinbaum, 1988). Boron is considered to be among the least mobile of the essential plant nutrients, and under natural conditions (soil-derived B), B redistribution from leaves is very limited (Epstein, 1973; Raven, 1980; Larcher, 1975; Loneragan et al., 1976). This view is based on the low concentrations of $B$ that are believed to exist in phloem sap (Oertli and Richardson, 1970), continuous B accumulation in leaves (Oertli, 1968; Picchioni et al., 199 1), and localized B deficiency (distortion) in meristematic tissues of plants growing in low-B environments (Gupta et al., 1985).

Several studies have shown that foliage-applied B is exported from treated prune and cherry leaves within days to weeks after an application (Hanson et al., 1985; Hanson, 1991b). However, the kinetics of uptake and export of foliage-applied B within the first $24 \mathrm{~h}$ subsequent to foliar application have apparently not been evaluated in fruit trees. In addition, differential leaf retention and uptake of foliage-applied nutrient solutions (Klein and Weinbaum, 1985) may be involved in the level of export of foliage-applied B, but these factors have also not been assessed among various fruit species. Further, it has been suggested that in olive, the mobilization of foliage-applied B is sink-regulated (Delgado et al., 1994),

Received for publication 8 Apr. 1994. Accepted for publication 29 July 1994.The cost of publishing this paper was defrayed in part by the payment of page charges. Under postal regulations, this paper therefore must be hereby marked advertisement solely to indicate this fact. therefore, this, too, may determine the capacity for export.

The purposes of this study were to evaluate 1) the kinetics of uptake and export of foliage-applied, labeled $\mathrm{B}$ between $\mathrm{O}$ and 24 $\mathrm{h}$ and between 1 and 20 days following application and 2) factors that may affect the export of foliage-applied B. These factors included the level of foliar retention of applied $\mathrm{B}$ solutions, the rate and quantity of $\mathrm{B}$ absorption, source-sink relations (e.g., presence or absence of adjacent fruit), and fruit species diversity (apple, pear, prune, and sweet cherry).

\section{Materials and Methods}

All measurements were made using intact, mature leaves on 'Red Delicious' apple, 'Bartlett' pear, 'French' prune, and 'Bing' sweet cherry trees growing in adjacent rows in an experimental orchard at Davis, Calif.

Three experiments were completed between 15 Aug. and 4 Sept. 1991. In all cases, B was applied by brief immersion of leaves in a solution of $1000 \mathrm{mg} \mathrm{B} /$ liter of deionized water in the form of ${ }^{10} \mathrm{~B}$ enriched boric acid (Eagle-Picher, Quapaw, Okla.), which contained 95.91 atomic percent ${ }^{10} \mathrm{~B}$. Boron exists naturally as $19.78 \%$ ${ }^{10} \mathrm{~B}$ and $80.22 \%{ }^{11} \mathrm{~B}$ (Handbook of Chemistry and Physics, 1985), although minor variation in ${ }^{10} \mathrm{~B}$ content (up to $1.04 \%$ of total $\mathrm{B}$ ) is known to occur in diverse geologic materials (Gregoire, 1987). The treatment solution included $0.05 \%$ (v/v) Triton X- 100 (Sigma, St. Louis) and had a final $\mathrm{pH}$ of 5.4. Preliminary results indicated that use of this surfactant at $0.05 \%$ (Swietlik and Faust, 1984) in the B treatment solution reduced variability in solution retention per unit leaf area by an average of $15 \%$ for all species, relative to applying $\mathrm{B}$ in water alone (data not shown). Preliminary findings also showed that no phytotoxicity occurred on leaves of any species following single or three daily, successive applications of $1000 \mathrm{mg} \mathrm{B} /$ liter, whereas multiple applications of $2000 \mathrm{mg} \mathrm{B} / \mathrm{liter}$ or greater resulted in leaf necrosis of all species within four days. 
Species variation in leaf retention, uptake, and export of labeled $B$ (Expts. 1 and 2). The possibility of species diversity in foliar retention, uptake, and export of the labeled B treatment solution was evaluated using shoot leaves on 4- to 5-year-old nonbearing trees. Linear regression equations were developed to assess the relationship between the amount of solution retained on leaves and leaf area. On 2 Aug., current-year shoots of all species and spurs (of apple only) were excised in the orchard, their cut ends were placed in tap water, and they were taken immediately to the laboratory. Leaves with petioles (34 to 62 shoot leaves per species, 20 apple spur leaves) were excised individually from the shoots or spurs, weighed, immersed in the B treatment solution (prepared with nonenriched boric acid), shaken gently to allow drainage of excess solution, and reweighed. Leaf areas were determined using an area meter (Delta-T; Decagon, Pullman, Wash.). For each species, this procedure included a representative range in leaf area. Paired species comparisons of regression slopes were made using the method of Snedecor and Cochran ( 1989) on MSTAT-C (Michigan State Univ., East Lansing). Data from the regression equations were then used to estimate the quantity of B retained (applied) per unit area.

Preliminary tests using detached apple and pear shoot leaves showed that solution retention varied by $<10 \%$ when $B$ was applied as an immersion compared with a standard spray treatment (data not shown). This indicated that immersion of leaves provided a close approximation of the amount of treatment solution which would be deposited from a spray treatment. Other methods of keeping account of the amount of B solution applied per unit leaf area (e.g., pipetting known volumes on leaves or placing 5- to 10$\mu \mathrm{l}$ drops on leaves) either resulted in poor application precision or insufficient label enrichment in leaves.

The first study (Expt. 1) to assess the uptake and export of foliage-applied, labeled B involved shoot leaves of 5-year-old apple trees and 4-year-old pear, prune, and sweet cherry trees. The trees were the same age as those used for leaf retention determinations. Two leaves from the middle portion of each of 10 wellexposed shoots of 5 replicate trees per species were tagged on the petiole. Within species, specific leaf weight varied by $<7 \%$ among leaves on these shoots (data not shown).

On 15 Aug., both leaves on each shoot were immersed in the B solution between 7:30 and $9 \mathrm{AM}$ and were subsequently excised (sampled) from the trees at the following times: $0.3 \mathrm{~h}$ (when the solution had visibly dried on the upper and lower leaf surfaces), 3 , 6,12 , and $24 \mathrm{~h}$, and $2,5,10,15$, and 20 days following the treatment. Control (nontreated) shoot leaves were sampled 1, 10, and 20 days following the treatment (two leaves from a separate nontreated shoot each day). The air temperature in the orchard during the treatment application period varied between 18 and $25 \mathrm{C}$, but visible drying of the solution occurred within $\approx 15$ to 20 min regardless of the air temperature.

At the time of sampling, petioles were removed and leaves were placed into plastic cups containing a known volume of deionized water. Leaves were then washed for $60 \mathrm{sec}$ with gentle mixing. This procedure provided the greatest recovery of nonabsorbed B remaining on leaf surfaces when compared with washing in $\mathrm{HC} 1$ $(0.01$ and $0.1 \mathrm{M})$ and $0.05 \%(\mathrm{v} / \mathrm{v})$ Tween 80 (data not shown). Twoand three-minute washing periods removed no additional $\mathrm{B}$, indicating that $60 \mathrm{sec}$ provided adequate washing. No B was detected in the washes of nontreated leaves, indicating that endogenous $\mathrm{B}$ was not leached during washing and that no $\mathrm{B}$ was present on leaf surfaces as contamination.

A small volume of the wash solution was taken to the laboratory for analysis. Each of the two procedures (treatment immersion and sampling and washing) required 10 to $15 \mathrm{~min}$. Leaves of each species were treated, sampled, and washed in identical order, which assured accuracy in the time that leaves of each species were removed from the shoots. After washing, leaves were immersed briefly in two 2-liter volumes of deionized water to remove any residual $\mathrm{B}$ adhering to the leaves from the washing solution. Leaves were then blotted dry with paper towels, placed in sealed bags, and taken to the laboratory in an ice chest. Total leaf area was determined for both leaves together as described above, then the leaves were dried for 3 days in an oven at $60 \mathrm{C}$. After recording leaf dry weight, leaves were ground to pass a 30 -mesh screen. Ground tissue was ashed overnight in a muffle furnace (500C), and the ash was dissolved in $1 \mathrm{~N} \mathrm{HNO}_{3}$ at room temperature. Total $\mathrm{B}$ in both leaf washings and the ashed extracts was measured according to the azomethine method of Wolf (1971) using a calorimeter with a $420 \mathrm{~nm}$ filter (PC 800; Brinkmann Instruments, Westbury, N.Y.). Control leaves were washed and then extracted for total $\mathrm{B}$ as described above, except the wash solutions were discarded.

To verify the accuracy of $B$ determination following the dry ashing procedure, random subsamples of leaf tissue from the above experiments were also analyzed by closed vessel microwave digestion, which effectively eliminates the possibility of B loss through volatilization. In all cases, the $\mathrm{B}$ concentrations in microwave digested samples were within $\pm 4 \%$ of the dry-ashed values. National Institute of Standards and Technology tissue standards with and without standard additions were also used to verify the accuracy of $B$ determinations (results not shown).

Boron uptake (absorption) on a leaf area $\left(\mathrm{cm}^{2}\right)$ basis at each sampling period was calculated as the difference between the quantity of $\mathrm{B}$ retained on the leaf surfaces (estimated by regression) and the quantity of B recovered in the wash (Levi, 1970; Klein and Weinbaum, 1985), both in $\mu \mathrm{g} \mathrm{B} / \mathrm{cm}^{2}$.

Boron isotopic ratios in the ashed extracts $\left({ }^{10} \mathrm{~B} /{ }^{11} \mathrm{~B}\right.$ ion counts/ see) were determined at each sampling period using an inductively coupled plasma mass spectrometer (Sciex 500; Perkin Elmer, Norwalk, Corm.). A certified isotopic solution (National Institute of Standards and Technology) was measured throughout analyses to assure the accuracy of sample isotopic ratios. The following equation was used to determine the fraction of $\mathrm{B}$ derived from the treatment $\left(\mathrm{B}_{\mathrm{dff}}\right)$ :

$$
\mathrm{B}_{\mathrm{dft}}=\left(\%{ }^{10} \mathrm{~B}_{\mathrm{t}}-\%^{10} \mathrm{~B}_{\mathrm{u}}\right) /\left(\%{ }^{10} \mathrm{~B}_{\mathrm{s}}-\%^{10} \mathrm{~B}_{\mathrm{u}}\right)
$$

The subscripts $t, u$, ands refer to the atomic percentages of ${ }^{10} \mathrm{~B}$ in the treated sample, the untreated (control) sample, and the treatment solution, respectively (adapted from Cabrera and Kissel,

Table 1. Uptake and export of foliage-applied, labeled B $24 \mathrm{~h}$ after application (Expt. 1). Data are expressed as the percentage of the amount of applied $B$ retained by the shoot leaf surfaces upon treatment $\left(\mu \mathrm{g} \mathrm{B} / \mathrm{cm}^{2}\right)$ or as the percentage of applied B absorbed $24 \mathrm{~h}$ after treatment. Cultivars are shown in Fig. 1 and the treatment procedure is shown in Fig. 2.

\begin{tabular}{|c|c|c|c|}
\hline \multirow[b]{2}{*}{ Species } & \multicolumn{2}{|c|}{ Retained quantity (\%) } & \multirow{2}{*}{$\begin{array}{c}\text { Export (\% of } \\
\text { absorbed quantity) }\end{array}$} \\
\hline & Uptake $^{y}$ & $\overline{\text { Export }^{x}}$ & \\
\hline Apple & $88 \pm 2$ & $79 \pm 3$ & $90 \pm 2$ \\
\hline Prune & $92 \pm 1$ & $74 \pm 2$ & $81 \pm 2$ \\
\hline Pear & $96 \pm 1$ & $77 \pm 5$ & $80 \pm 5$ \\
\hline Sweet Cherry & $96 \pm 1$ & $76 \pm 1$ & $79 \pm 1$ \\
\hline
\end{tabular}

$\overline{{ }^{2} \text { Each value is the mean } \pm \text { SE of five tree replicates (two leaves on a single }}$ shoot).

'Uptake calculated as in Fig. 2.

${ }^{x}$ Export calculated as in Fig. 3 . 


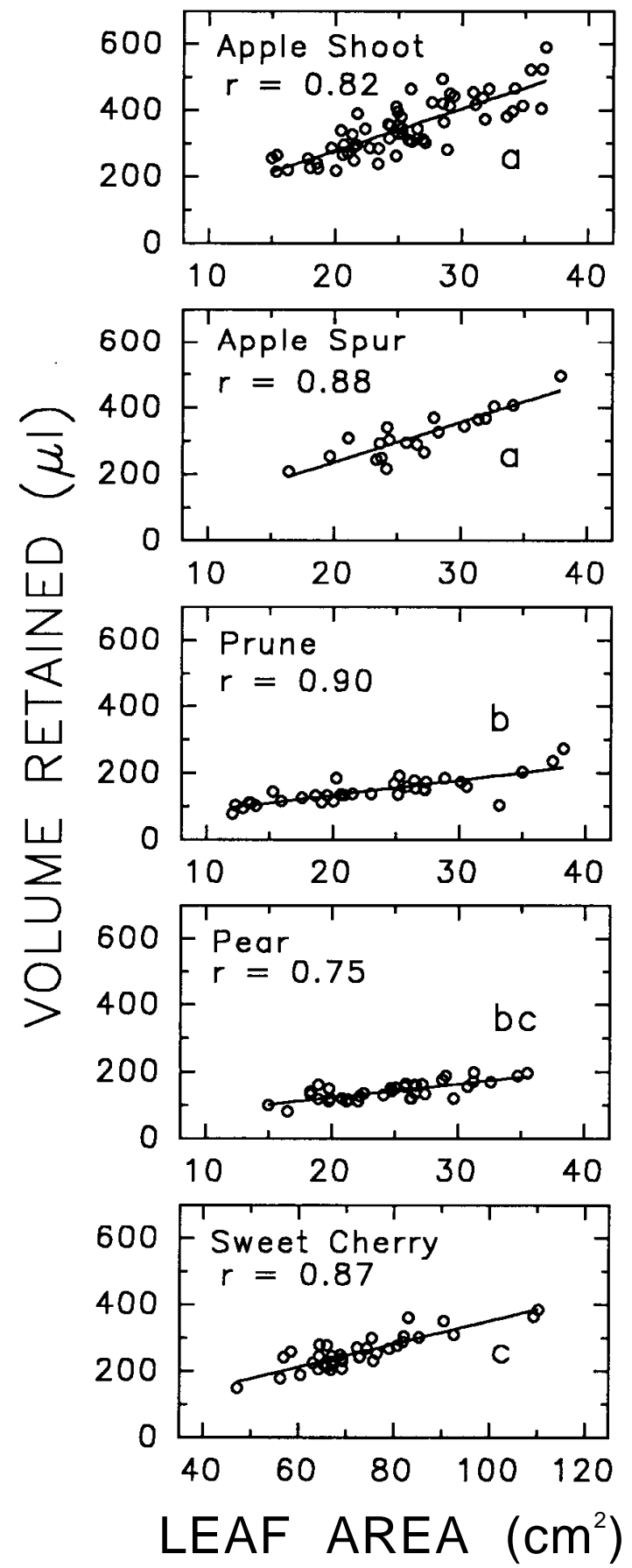

Fig. 1. Relationship between leaf area per single leaf and the total volume of $B$ treatment solution $(1000 \mathrm{mg} \mathrm{B} / \mathrm{liter}+0.05 \% \mathrm{v} / \mathrm{v}$ Triton $\mathrm{X}-100)$ retained per leaf. Cultivars from top: 'Red Delicious' apple, 'French' Prune, 'Bartlett' pear, and 'Bing' sweet cherry, All data correspond to shoot leaves unless specified, Regression equations: apple shoot: $\mathrm{y}=23.49+12.70 \mathrm{x}(r=0,82, \mathrm{~N}=62)$; apple spur: $\mathrm{y}=-4.43+12.05 \mathrm{x}(r=0.88, \mathrm{~N}=20)$; prune: $\mathrm{y}=31.80+5.14 \mathrm{x}(r=0,90$, $\mathrm{N}=34)$; peat $\mathrm{y}=40.64+4,13 \mathrm{x}(r=0.75, \mathrm{~N}=37)$; sweet cherry: $\mathrm{y}=5.94+3.45 \mathrm{x}$ $(r=0.87, \mathrm{~N}=37)$. Regression lines with the same letter have slopes that are not significantly different at $P=0.05$. Each correlation coefficient $(\boldsymbol{r})$ is significant at $P=0.01$.

1989). Boron isotopic ratios for untreated leaf samples were obtained the same day of treatment (just before B application). The average percentage of ${ }^{10} \mathrm{~B}$ in untreated shoot leaves ranged between $20.12 \%$ and $20.34 \%$, depending on species ( $\mathrm{CV}$ of $0.6 \%$ to $2.4 \%)$. The species averages were used in all calculations. Within fruit species, the $\mathrm{B}_{\mathrm{u}}$ values on trees used in Expts. 2 and 3 varied from the above percentages by $<2 \%$ (data not shown).

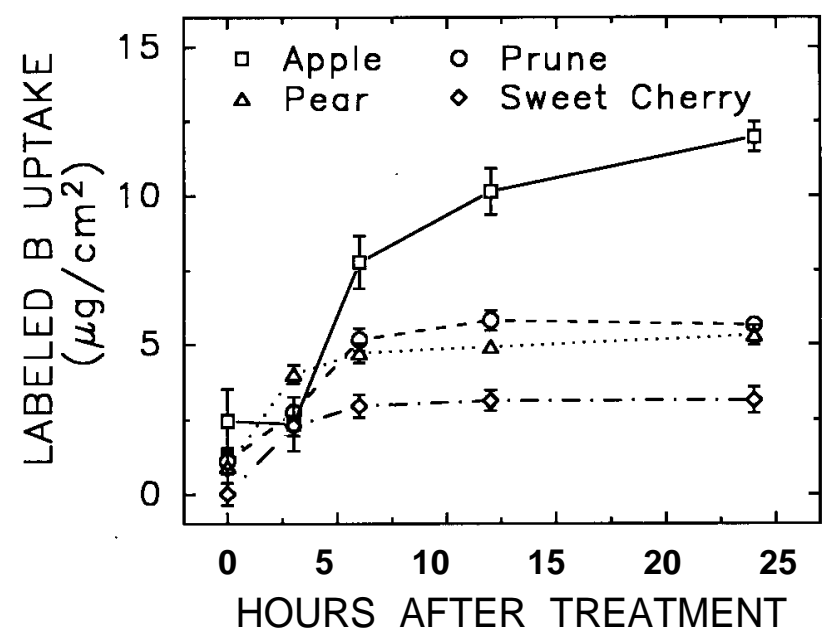

Fig. 2. Uptake of foliage-applied, labeled B by shoot leaves in Expt. 1, expressed as absolute quantity, Leaves were immersed in $1000 \mathrm{mg} \mathrm{B} / \mathrm{liter}\left(95.91 \%{ }^{10} \mathrm{~B}\right.$ and $\left.4.09 \%{ }^{11} \mathrm{~B}\right)+0.05 \%(\mathrm{v} / \mathrm{v})$ Triton $\mathrm{X}-100$ on 15 Aug., and uptake was monitored during the subsequent $24 \mathrm{~h}$. Time at $0 \mathrm{~h}$ refers to 15 to $20 \mathrm{~min}$ following application (when leaf surfaces had visibly dried). Uptake was calculated as the difference between the labeled B quantity applied (retained) in $\mu \mathrm{g} \cdot \mathrm{cm}^{-2}$ (estimated by species regression equations in Fig. 1) and that measured in the leaf washings at each time period $\left(\mu \mathrm{g} \cdot \mathrm{cm}^{-2}\right)$. Cultivars are shown in Fig. 1. Each value is the mean \pm SE of five tree replicates (two leaves on a single shoot).

Total B concentrations of treated and untreated leaves were multiplied by the specific leaf weights to obtain total $\mathrm{B} / \mathrm{cm}^{2}$ of leaf area. For treated leaves, this value was further multiplied by $B_{\mathrm{dnt}}$, to obtain labeled (applied) B per $\mathrm{cm}^{2}$ at each time period. Export of labeled $\mathrm{B}$ was calculated at each time period using the following equation:

Export $\left(\mu \mathrm{gB} / \mathrm{cm}_{2}\right)=\mu \mathrm{g}$ labeled B absorbed $/ \mathrm{cm}^{2}-\mu \mathrm{g}$ labeled $\mathrm{B}$ in leaf extract $/ \mathrm{cm}^{2}$

Since only $\approx 1 \%$ of the applied B could be recovered in the washes by the fifth day, the absorption (uptake) value of Eq. [2] on day 5 and later was equivalent to the estimated quantity of applied B.

A second study (Expt. 2) was made to evaluate the relationship between nonlabeled and labeled $\mathrm{B}$ in shoot leaves between 1 and 20 days. Trees of all species were 3 years old. Methods were identical to those of Expt. 1, except three successive, daily applications of labeled B were made (13-15 Aug.) and shoot leaf samples were collected $1,2,3,4,5,10,15$, and 20 days following the last treatment. Data were expressed as the total and labeled B content in the treated leaves on each date and the total B content in control leaves on neighboring shoots.

Influence of sink demand on export of labeled B (Expt.3). Labeled B was applied to two mature leaves (as described above) on spurs of three adjacent 7-year-old 'Red Delicious' trees. Spurs were either fruiting $(+\mathrm{F})$ or nonfruiting $(-\mathrm{F})$; all $+\mathrm{F}$ spurs contained a single fruit (average fruit dry weight of $27 \pm 2 \mathrm{~g}$ ). Two successive, daily applications of labeled B were made ( 13-14 Aug.). The spur leaves were washed, processed, and analyzed for total and labeled $\mathrm{B}$, as described above, 1, 5, and 10 days following the second immersion. Total B per leaf area was determined on an equal number of $+\mathrm{F}$ and $-\mathrm{F}$ nontreated (control) spurs on days 1 and 10 only (14 and 24 Aug., respectively). The total and labeled B quantity per fruit on days 1 and $10(+\mathrm{F}$ treated spurs $)$ and the total $\mathrm{B}$ per fruit on day 10 only $(+\mathrm{F}$ nontreated spurs) were also measured as described for leaves. Fruit, which were not treated with labeled B, were processed for analyses using the method of 


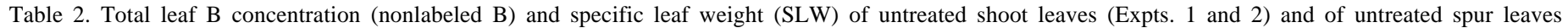
(Expt. 3) at the time of a single application of labeled B to treated leaves and of the last of multiple applications to treated leaves ( 15 Aug. in all Expts.). Tree age was 5 years for apple and 4 years for pear, prune, and sweet cherry (Expt. 1, nonbearing); 3 years for all species (Expt. 2, nonbearing); and 7 years (Expt. 3, bearing). Spurs of Expt. 3 were either fruiting (+F) or nonfruiting (-F). Cultivars are listed in Fig. $1^{2}$.

\begin{tabular}{|c|c|c|c|c|c|c|c|c|}
\hline \multirow[b]{4}{*}{ Species } & & & & & \multicolumn{4}{|c|}{ Expt. 3} \\
\hline & \multicolumn{2}{|c|}{ Expt. 1} & \multicolumn{2}{|c|}{ Expt. 2} & \multirow{2}{*}{\multicolumn{2}{|c|}{$\begin{array}{r}\text { B c o n c n } \\
\left(\mathrm{mg} \cdot \mathrm{kg}^{-1} \text { dry wt }\right)\end{array}$}} & \multirow{2}{*}{\multicolumn{2}{|c|}{$\begin{array}{c}\mathrm{SLW} \\
\left(\mathrm{mg} \cdot \mathrm{cm}^{-2}\right)\end{array}$}} \\
\hline & B concn & \multirow{2}{*}{$\begin{array}{c}\mathrm{SLW} \\
\left(\mathrm{mg} \cdot \mathrm{cm}^{-2}\right)\end{array}$} & \multirow{2}{*}{$\begin{array}{c}\text { B concn } \\
\left(\mathrm{mg} \cdot \mathrm{kg}^{-1} \text { drywt }\right)\end{array}$} & \multirow{2}{*}{$\begin{array}{c}\mathrm{SLW} \\
\left(\mathrm{mg} \cdot \mathrm{cm}^{-2}\right)\end{array}$} & & & & \\
\hline & $\left(\mathrm{mg} \cdot \mathrm{kg} \quad{ }^{-1}\right.$ drywt) & & & & $+\mathrm{F}$ & $-\mathrm{F}$ & $+\mathrm{F}$ & $-\mathrm{F}$ \\
\hline Apple & $56.6 \pm 2.4$ & $11.9 \pm 0.5$ & $44.5 \pm 2.0$ & $12.0 \pm 0.3$ & $51.2 \pm 0.3$ & $48.3 \pm 2.3$ & $8.1 \pm 0.2$ & $8.1 \pm 0.5$ \\
\hline Pear & $43.6 \pm 2.3$ & $11.7 \pm 0.7$ & $42.0 \pm 2.0$ & $11.1 \pm 0.3$ & & & --- & --- \\
\hline Prune & $52.9 \pm 0.5$ & $11.7 \pm 0.6$ & $46.7 \pm 1.3$ & $11.1 \pm 0.4$ & & & & \\
\hline Sweet Cherry & $67.1 \pm 2.6$ & $11.4 \pm 0.6$ & $61.0 \pm 3.2$ & $11.0 \pm 0.3$ & & --- & & \\
\hline
\end{tabular}

'Each value is the mean \pm SE of five tree (single shoot) replicates (Expts. 1 and 2) or three tree (double spur) replicates (Expt. 3).

Van Goor (1971).

For Expts. 1 and 2, all data are reported as the mean \pm SE of five tree replicates; each tree replicate consisted of two leaves on a single shoot. Observations of Expt. 3 are given as the mean \pm SE of three tree replicates; each tree replicate consisted of duplicate spurs for both treated and nontreated spurs. All calculations of applied (labeled) $\mathrm{B}$ account for ${ }^{10} \mathrm{~B}$ and ${ }^{11} \mathrm{~B}$, which were present in the treatment solution as $95.91 \%$ and $4.09 \%$ of the total $\mathrm{B}$, respectively. No rainfall occurred during the study period.

\section{Results}

Foliar retention, uptake, and export of applied B (Expt. 1). Shoot leaf retention of the B-containing solution varied among the species (Fig. 1). On average, apple shoot leaves retained over twice the volume of treatment solution per leaf area $\left(13.7 \pm 0.2 \mu \mathrm{l} \cdot \mathrm{cm}^{-2)}\right.$ as compared to prune and pear shoot leaves $\left(6.7 \pm 0.2 \mu \mathrm{l} \cdot \mathrm{cm}^{-2}\right.$ and $5.8 \pm 0.1 \mu \mathrm{l} \cdot \mathrm{cm}^{-2}$, respectively), and almost four times the amount retained by sweet cherry shoot leaves $\left(3.5 \pm 0.1 \mu \mathrm{l} \cdot \mathrm{cm}^{-2}\right)$. Apple spur leaves retained an average of $11.9 \pm 0.3 \mu \mathrm{l} \cdot \mathrm{cm}^{-2}$, or $13 \%$ less volume than apple shoot leaves, but the regression slopes did not differ significantly. Since the treatment solution was $1000 \mathrm{mg} \mathrm{B} /$ liter, these values are equivalent to the quantity $(\mu \mathrm{g})$ of $B$ retained

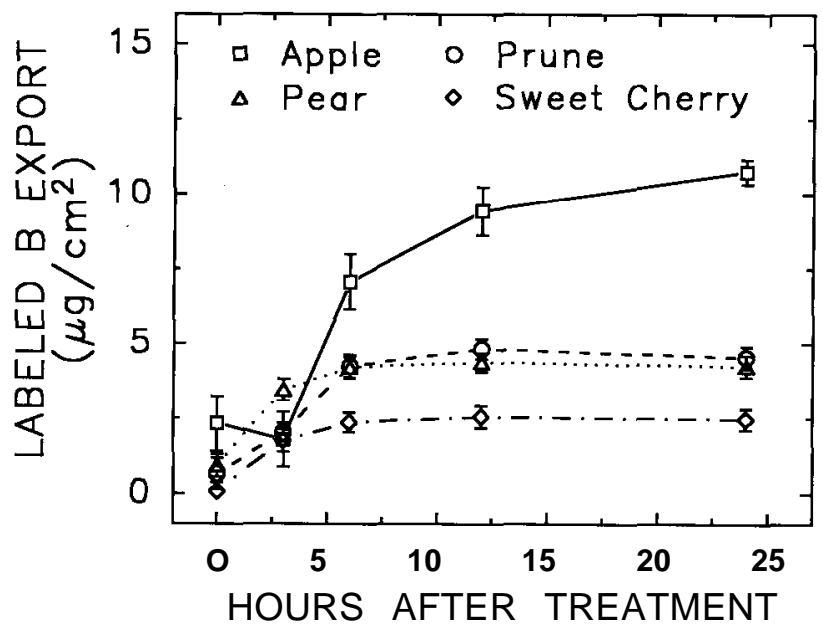

Fig. 3. Export of foliage-applied, labeled B by shoot leaves in Expt. 1, expressed as absolute quantity. Time at $0 \mathrm{~h}$ refers to 15 to $20 \mathrm{~min}$ following application (when leaf surfaces had visibly dried). Export was calculated as the difference between the quantity of labeled B uptake (Fig. $2, \mu \mathrm{g} \cdot \mathrm{cm}^{-2}$, and the quantity of labeled B measured in the leaf tissue extract at each time period $\left(\mu \mathrm{g} \cdot \mathrm{cm}^{-2}\right)$. Cultivars are shown in Fig. 1 and the treatment procedure is shown in Fig. 2. Each value is the mean \pm SE of five tree replicates (two leaves on a single shoot). per $\mathrm{cm}^{2}$. In all cases, the volume (pi) of treatment solution retained per leaf was significantly correlated with leaf area (Fig. 1).

In the following results and discussion, the term absorbed refers to applied (labeled B) that could not be removed by washing. This usage is appropriate since $>95 \%$ of the applied B not removed by washing was eventually translocated out of the leaf (see following results).

Species differences in solution retention per shoot leaf area resulted in parallel differences in the quantity of $\mathrm{B}$ absorbed by the leaves (Fig. 2). By 24 h, $88 \%$ to $96 \%$ of the applied B retained on the leaf surfaces had been absorbed by all species (Table 1). At this time, apple leaves absorbed about twice as much B per unit leaf area as prune and pear leaves, and over three times more $B$ than sweet cherry leaves. The rate of $\mathrm{B}$ uptake by all species was greatest during the first $6 \mathrm{~h}$, after which comparatively small incremental increases were detected by 12 and $24 \mathrm{~h}$. Following the 15 to 20 min drying of the treatment solution ( $\mathrm{O}$ h in Fig. 2), apple leaves did not absorb further quantities of $\mathrm{B}$ during the subsequent $3 \mathrm{~h}$, whereas appreciable amounts of $\mathrm{B}$ were absorbed during the first $3 \mathrm{~h}$ by the other species.

Although variable, measurable B uptake occurred during the 15 to 20 min drying period $(\mathrm{O} h)$ in leaves of all species except sweet cherry, representing $17 \%$ to $18 \%$ of leaf retention. However, $>80 \%$ of the uptake by all species occurred after the solution had visibly dried. Boron uptake by leaves of pear, prune, and sweet cherry was essentially completed by $48 \mathrm{~h}$ (99\% of the quantity retained), whereas apple leaves required 5 days to absorb all of the application (data not shown).

By $24 \mathrm{~h}$ following foliage application, the measured shoot leaf B concentrations of all species had reached a maximum and were increased by $\approx 3$ - fold in apple, prune, and pear and $\approx 2$-fold in sweet cherry relative to the control (untreated) shoot leaf concentrations measured $24 \mathrm{~h}$ earlier. Boron concentrations in untreated leaves of all species (15 Aug.) ranged between 44 and $67 \mathrm{mg} \cdot \mathrm{kg}^{-1}$ dry weight (Table 2). These concentrations did not change measurably during the 20-day period following treatment (data not shown) and are typical for these species in local conditions this time of year. Untreated sweet cherry shoot leaves tended to have the greatest B concentration compared to untreated shoot leaves of the other species. There was only minor species variation in shoot leaf specific leaf weight (SLW) values (Table 2).

Species rankings with respect to the quantity of labeled B exported during the first $24 \mathrm{~h}$ were identical to those of solution retention and uptake. By $24 \mathrm{~h}$, apple shoot leaves exported over twice the amount of labeled B as prune and pear shoot leaves and about four times the amount of sweet cherry shoot leaves (Fig. 3). Export by leaves of pear and sweet cherry occurred continuously 


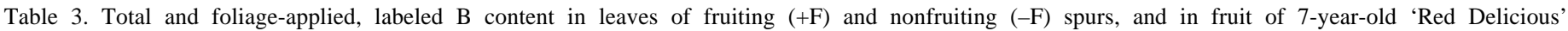
trees during 15-24 Aug. (Expt. 3). Fruit (on treated spurs) and the control leaves were not exposed to the B treatment solution. Treated leaves of $+\mathrm{F}$ and $-\mathrm{F}$ spurs were exposed to $\mathrm{B}$ as described in Fig. 2, but on two successive dates (13 and 14 Aug.).

Leaf $\mathrm{B}$ content $\left(\mu \mathrm{g} \cdot \mathrm{cm}^{-2}\right)$

Days after

last treatment

1

5

$10^{x}$

B export ${ }^{\mathrm{w}}$
Labeled B

$+\mathrm{F} \quad-\mathrm{F}$

$3.03 \pm 0.32$

$1.82 \pm 0.08$

$0.75 \pm 0.07$

$2.84 \pm 0.32$

$1.20 \pm 0.16$

$0.77 \pm 0.01$

$2.07 \pm 0.32$
Total B

$\begin{array}{cc}\quad+\mathrm{F} & -\mathrm{F} \\ 3.36 \pm 0.32 & 3.12 \pm 0.31 \\ 2.16 \pm 0.11 & 1.51 \pm 0.18 \\ 1.07 \pm 0.08 & 1.09 \pm 0.01 \\ 2.29 \pm 0.30 & 2.03 \pm 0.31\end{array}$

Fruit B

content ( $\mu \mathrm{g} /$ fruit)

$\begin{array}{cc}\text { Control }^{y} & \text { Labeled B } \\ 0.40 \pm 0.01 & - \\ - & - \\ 0.36 \pm 0.02 & 187 \pm 45\end{array}$

Total B

${ }^{2}$ Each value is the mean \pm SE of three tree replicates. Each replicate consists of two leaves or one fruit on each of two spurs per tree.

${ }^{y}$ Pooled average of $+\mathrm{F}$ and $-\mathrm{F}$ spur leaves.

${ }^{x}$ Day of fruit harvest.

"Difference in B content between 1 and 10 days following treatment

between 0 and $6 \mathrm{~h}$, in prune between 0 and $12 \mathrm{~h}$, and in apple throughout the 24-h duration. By $24 \mathrm{~h}, 74 \%$ to $79 \%$ of the $\mathrm{B}$ retained initially on the leaf surfaces was exported, and apple shoot leaves seemed to export the most labeled B as a function of the absorbed quantity at $24 \mathrm{~h}$ (Table 1 ).

Export at $\mathrm{O} h$ (following the 15 to 20 min drying period) was variable but nonetheless detectable in all but sweet cherry leaves and lagged only slightly behind uptake during the 24-h period (compare Fig. 3 to Fig. 2). Even after $6 \mathrm{~h}$, the species had exported $52 \%$ to $72 \%$ of their initial foliar retention.

Labeled B export also occurred in all species between $24 \mathrm{~h}$ and 20 days after treatment, as indicated by the decreasing values of labeled Bin leaves during this period (Fig. 4). Exported quantities during this time (0.63 to $\left.1.12 \mu \mathrm{g} \mathrm{B} / \mathrm{cm}^{2}\right)$ were relatively small compared to the first $24 \mathrm{~h}$ (Fig. 3) and represented only $5 \%$ to $19 \%$ of the initial shoot leaf retention, depending on species. By 20 days, labeled B content in shoot leaves of prune, pear, and sweet cherry averaged $0.06 \mu \mathrm{g} \cdot \mathrm{cm}^{-2}$ compared to $0.50 \mu \mathrm{g} \cdot \mathrm{cm}^{-2}$ for apple shoot leaves. From $1 \%$ to $4 \%$ of the original applied B quantity (amount retained per unit leaf area upon treatment) was present in the leaves 20 days after treatment.

Relationship between total and labeled B exported (Expt. 2). One day following three successive, daily applications of the B solution, shoot leaf B concentrations were 3.2- to 5.4-fold greater than controls (untreated averages of $42-61 \mathrm{mg} \cdot \mathrm{kg}^{-1} \mathrm{dry}$ weight), which were sampled three days earlier (Table 2). As in Expt. 1, nontreated sweet cherry shoot leaves had the greatest B concentration of all species.

On a shoot leaf area basis, total B was increased by 5.4 to 5.6 times the control levels in apple and pear, 4.4 times in prune, and 3.3 times in sweet cherry 1 day after the last application (Fig. 5). Thereafter, total leaf $\mathrm{B}$ content decreased sharply between days 1 and 5 , to a smaller extent between days 5 and 10 , and at each measurement period, in parallel to the reductions in labeled $\mathrm{B}$ content. The area between the total and labeled $B$ curves is approximately equivalent to the total $\mathrm{B}$ content in the control (untreated) leaves on neighboring shoots. Additional B export occurred in all species between 10 and 20 days following treatment, so that by 20 days, the labeled B content averaged 0.43,0.15, 0.16 , and $0.07 \mu \mathrm{g} \cdot \mathrm{cm}^{-2}$ in shoot leaves of apple, prune, pear, and sweet cherry, respectively (data not shown).

Sink demand and export of labeled $B$ (Expt. 3). Immersion of 'Red Delicious' spur leaves in the labeled B solution on 2 successive days increased total leaf $\mathrm{B}$ content per $\mathrm{cm}^{2}$ by about eight times the levels of nontreated control spur leaves (day 1 in Table 3). Control leaves of $+\mathrm{F}$ and $-\mathrm{F}$ spurs at 1 and 10 days were identical in total B content per leaf area; thus, these data were pooled. SLW of apple spur leaves, which was not affected by fruiting, averaged $33 \%$ less than SLW of apple shoot leaves (Table 2).

Between 1 and 10 days, leaves of both $+\mathrm{F}$ and $-\mathrm{F}$ treated spurs exported similar quantities of labeled $\mathrm{B}$ on both an absolute basis (Table 3) and as a percentage of the day 1 value (data not shown). The quantities of labeled and total B exported between 1 and 10 days following the last treatment were nearly identical for $+\mathrm{F}$ spurs as well as for-F spurs, indicating that the applied $\mathrm{B}$ represented the exported fraction.

Ten days following treatment, the average percentage of ${ }^{10} \mathrm{~B}$ in the fruit from B-treated spurs was $33.65 \pm 2.10$ compared to 19.58 \pm 0.17 for the fruit from untreated spurs, confirming that transport of labeled B from leaves to fruit had occurred. Sixteen percent of the total fruit $\mathrm{B}$ content at harvest was derived from previous immersion of adjacent spur leaves in the labeled B solution (Table 3). However, total $B$ concentrations in fruit from treated and nontreated spurs did not differ $\left(40 \pm 5\right.$ and $41 \pm 2 \mathrm{mg} \cdot \mathrm{kg}^{-1} \mathrm{dry}$ weight, respectively). Fruit on B-treated $(+\mathrm{F})$ spurs accumulated $17 \%$ of the total B applied per spur (two applications), which averaged $1083 \pm 118 \mu \mathrm{g} /$ two spur leaves.

Between 1 and 10 days following the last $\mathrm{B}$ application, an average of $104 \mu \mathrm{g}$ of labeled B was exported by leaves, which were sampled on day 10 (initial quantity estimated using day 10 treated spur leaf area and the labeled B content per leaf area for day 1 samples). This accounted for only $55 \%$ of the average 10-day

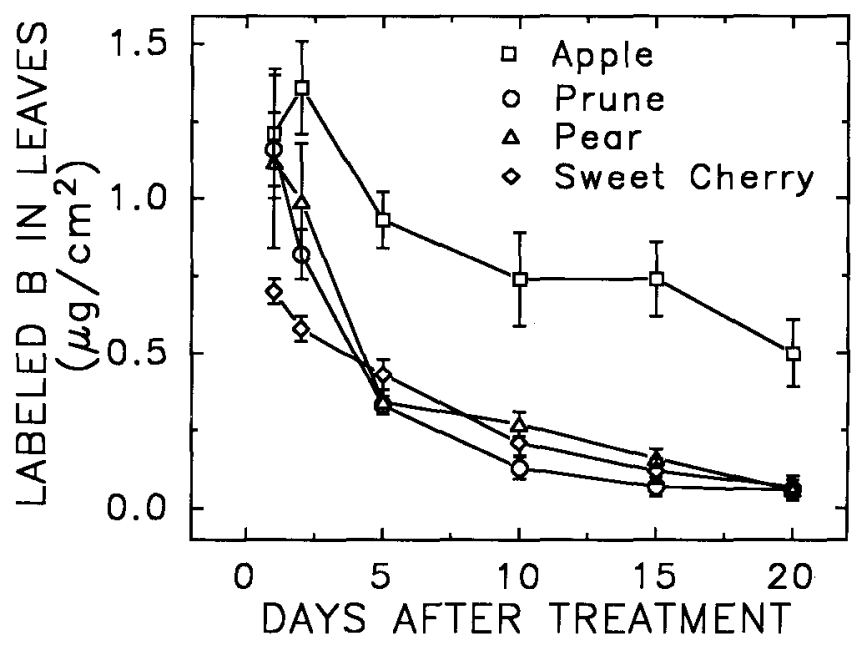

Fig, 4. Labeled B content (from foliage application) in shoot leaves of Expt. 1. Each value is the mean \pm SE of five tree replicates (two leaves on a single shoot). Cultivars are shown in Fig. 1 and the treatment procedure is shown in Fig. 2. 


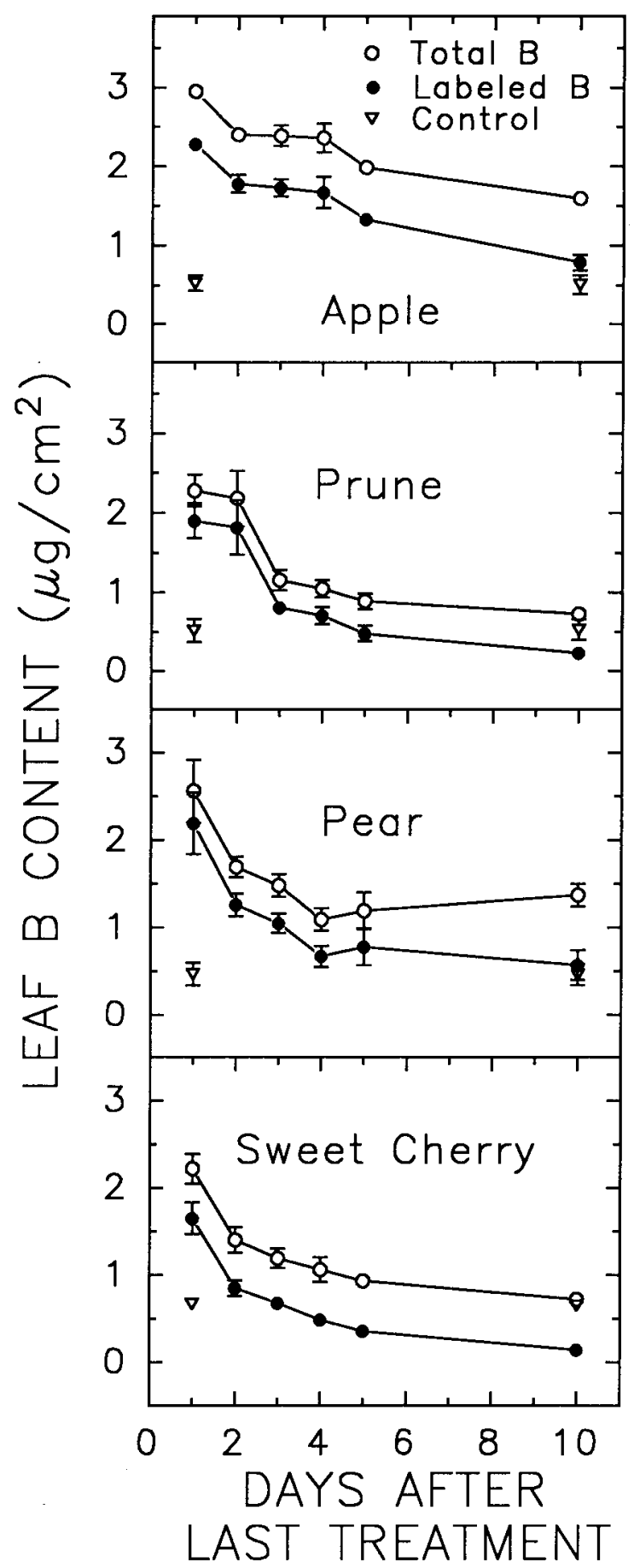

Fig.5.TotalandlabeledBintreatedshootleaves and the total B in nontreated (control) shoot leaves of Expt. 2. Treated leaves were exposed to B as described in Fig. 2, but on three successivedates(13-1 5 Aug.).LeafBis shown 1 to 10 days following the last treatment application for apple,prune,pear,andsweetcherry.Controlleaves(triangles)are shown onlyforland10days following the last application.Cultivars are shown in Fig. 1. Each valueisthemean \pm SEoffive tree replicates (two leaves on a single shoot).Insome cases, the SE is smaller than the symbol.

accumulation of labeled B per fruit, indicating that export of applied B was initiated before the day 1 measurement as would be expected from Expt. 1 above.

\section{Discussion}

Shoot leaf retention of the B treatment solution differed greatly among the four species tested,and this differential was a principal determinant of the uptake and export capacity of foliage-applied, labeled B. The fact that most of the uptake occurred following the visible drying period was not unexpected, since it is known that foliar uptake of applied nutrients can continue for several days following an application (Newmann, 1988). Thus, the dried appearance of the applied solution on the leaf surface (visually apparent 15 to $20 \mathrm{~min}$ following the application) probably oversimplifies the physiochemical state of $\mathrm{B}$ on or beneath the leaf surface.

Uptake proceeded to near completion within $24 \mathrm{~h}$ and was limited solely by the amount of $\mathrm{B}$ that could be retained by the shoot leaf surfaces. Export, in turn, was closely related to the quantity of $\mathrm{B}$ absorbed. Similar differences in retention of ${ }^{32} \mathrm{P}$ solutions were reported by Tukey (1952), and are probably related to variation in leaf surface characteristics. For example, apple leaves are characterized by microscopically visible, nonglandular hairs, which may number up to $80 / \mathrm{cm}^{2}$ and exceed $100 \mathrm{pm}$ in length (Plourde et al., 1985). Even among apple clones, significant variation in leaf pubescence has been documented (Paiva and Janick, 1980). Therefore, genotypic differences in leaf surface characteristics may determine the quantity of foliage-applied B retained and absorbed by fruit species and cultivars.

Wittwer and Teubner (1959) suggested that urea-N is absorbed as fast as any nutrient applied to plant foliage. The findings in Fig. 2 and Table 1 indicate that the rate of B uptake by these species (as a percent of applied quantity) was similar to the rate of urea uptake by leaves of almond and olive during comparable absorption periods (Klein and Weinbaum, 1985). This finding maybe related to common physiochemical properties of urea and boric acid. Urea, an uncharged molecule, is known to penetrate cuticular membranes 10 to 20 times faster than ions (Franke, 1967). Boron exists essentially $100 \%$ in the form of uncharged boric acid at a $\mathrm{pH}$ of 7 or below (Oertli and Grgurevic, 1975). Urea and boric acid are similar in size (molecular weights of 60 and 62, respectively), and both promote cuticular permeation and foliar absorption of other molecules (Wittwer et al., 1965; Crafts, 1956). The possibility of cuticular B adsorption cannot be discounted. However, such bound B pools would presumably be detected in leaf analyses, and based on analyses in our study (e.g., Figs. 3 and 4), any irreversibly bound, labeled B fractions would represent a minimal proportion of the applied quantity.

The reproducibility of the $B$ analyses was rigorously tested using analytical B standards, spike additions and two distinct digestion procedures. Although we did not directly determine the fate of the labeled B (which would have required whole-tree excavation), we used the technique of King and Zeevaart (1974) and recorded measurable accumulation of labeled $B$ in petiole exudation media of prune and apple shoot leaves within $2 \mathrm{~h}$ of application (labeled B applied to intact leaves in the orchard as described in methods and leaves detached $2 \mathrm{~h}$ later; unpublished data). Thus, the decline in leaf B contents in this study could only be attributed to export of the label out of the leaf.

The findings also demonstrate that the export of foliage-applied $\mathrm{B}$ occurred rapidly (within $6 \mathrm{~h}$ of application) in all four fruit species tested. Rapid responses of B-deficient fruit trees to foliage applications of B in the field have previously been summarized (Swietlik and Faust, 1984). Very similar results were obtained for all species when evaluated between 21 Oct. and 10 Nov. (>90\% of retained quantities absorbed and $70 \%$ to $80 \%$ of retained quantities exported within $24 \mathrm{~h}$; data not shown). By 10 Nov., sweet cherry shoot leaves had begun to abscise naturally. This indicates that leaf age (between August and November) was of little consequence in determining the capacity for export.Hanson(1991b)stated that the 
most rapid export of foliage-applied B (500 mg-liter $\left.{ }^{-1}\right)$ from apple, pear, prune, and sour cherry spur leaves occurred 3 to 9 days after treatment, but the possibility of earlier export was not evaluated in that study.

Evidence that significant export of foliage-applied B occurs rapidly in these species is also provided by the lack of visible phytotoxicity in leaves evaluated in these experiments. Undoubtedly, toxic B concentrations (500 to $1000 \mathrm{mg} \cdot \mathrm{kg}^{-1}$ dry weight for the application rate used) would have been detected in the leaves had the export not rapidly occurred. In Expt. 1, however, the maximum recorded shoot leaf $\mathrm{B}$ concentrations $(24 \mathrm{~h}$ after treatment) were below $225 \mathrm{mg} \mathrm{B} / \mathrm{kg}$ dry weight and characteristic symptoms of B toxicity did not appear.

The use of isotopes (e.g., ${ }^{10} \mathrm{~B}$-enriched boric acid) permits direct measurement of the translocation of foliage-applied B within the plant (Charnel, 1986; Wittwer et al., 1965). Based on data in Table 3 and Fig. 5, the labeled B absorbed by leaves of all species represented the mobilized fraction. A similar conclusion was reached by Hanson ( 1991 b).

The high mobility of foliage-applied B may have resulted from transport of B in a form not normally present in the plant (Van Goor and Van Lune, 1980) or from the accessibility and entry of B into a route that is unavailable under natural conditions (Pate, 1975). The relative mobility of foliage-applied B in leaves of these species, in apparent contrast to soil-derived B in leaves, indicates that foliar B fertilization maybe an effective solution to transient B deficiencies and as such would have Particular value as a means of supplying rapidly growing tissue such as flowers and fruits.

Labeled B was exported from the apple spur leaves at a similar rate and quantity irrespective of the spur cropping status. However, significant amounts of the foliage-applied label were transported to the fruit. This occurred even though this study was limited to a 10-day interval when the fruit were essentially mature. The extent of redistribution of foliage-applied B to apples has been questioned by Bramlage et al. (1980), who cited the prevailing idea that B is an immobile element. Further study that includes the application of labeled B over the duration of the growing season (particularly during the flowering period), is needed to determine whether foliage-applied Bat other times can supply significant B to satisfy flower and fruit demands in a range of tree fruit species and to compare the relative importance of translocated B and B directly absorbed by buds.

\section{Literature Cited}

Batjer, L.P. and A.H. Thompson. 1949. Effect of boric acid sprays applied during bloom upon the set of pear fruits. Proc. Amer. Soc. Hort. Sci. 53:141-142.

Bramlage, W. J., M. Drake, and W.J. Lord. 1980. The influence of mineral nutrition on the quality and storage performance of pome fruits grown in North America, p. 29-39. In: D. Atkinson, J.E. Jackson, R.O. Sharples, and W.M. Wailer (eds.). Mineral nutrition of fruit trees. Butterworths, Boston.

Cabrera, M.L. and D.E. Kissel. 1989. Review and simplification of calculations in ${ }^{15} \mathrm{~N}$ tracer studies. Fert. Res. 20:11-15.

Charnel, A. 1986. Survey of different approaches to determine the behavior of chemicals directly applied to aerial parts of plants, p. 66-86. In: A. Alexander (cd.). Developments in plant and soil sciences. vol. 22. Martinus Nijhoff, Boston.

Crafts, A.S. 1956. The mechanism of translocation: methods of study with ${ }^{14}$ C-labeled 2,4-D. Hilgardia 26:287-334.

Delgado, A., M. Benlloch, and R. Fernández-Escobar. 1994. Mobilization of boron in olive trees during flowering and fruit development. HortScience 29:616-618.

de Wet, E., P.J. Robbertse, and H.T. Groeneveld. 1989. The influence of temperature and boron on pollen germination in Magnifera indica L. S. Afr. J. Plant. Soil 6:228-234.

Epstein, E. 1973. Flow in the phloem and the immobility of calcium and boron: A new hypothesis in support of an old one. Experiential 29: 133134.

Franke, W. 1967. Mechanisms of foliar penetration of solutions. Annu. Rev. Plant. Physiol. 18:281-300.

Gregoire, D.C. 1987. Determination of boron isotopic ratios in geologic materials by inductively coupled plasma mass spectrometry. Anal. Chem. 59:2479-2484.

Gupta, U.V., Y.W. Jame, C.A. Campbell, A.J. Leyshon, and W. Nicholaichuk. 1985. Boron toxicity and deficiency: A review. Can. J. Soil. Sci. 65:381-409.

Handbook of Chemistry and Physics. 1985. 66th ed. CRC Press, Boca Raton, Fla. p. B-10.

Hanson, E.J. 1991a. Sour cherry trees respond to foliar boron applications. HortScience 26:11 42-1 145.

Hanson, E.J. 1991 b. Movement of boron out of tree fruit leaves. HortScience 26:271-273.

Hanson, E. J., M.H. Chaplin, and P.J. Breen. 1985. Movement of foliar applied boron out of leaves and accumulation in flower buds and flower parts of 'Italian' prune. HortScience 20:747-748.

Holevas, C.D. and D.A. Biris. 1980. Bitter pit-like symptoms in quinces: Effect of calcium and boron sprays on the control of the disorder,p.319326. In: D. Atkinson, J.E. Jackson, R.O. Sharples, and W.M. Wailer (eds.). Mineral nutrition of fruit trees. Butterworths, Boston.

King, R.W. and J.A.D. Zeevaart. 1974. Enhancement of phloem exudation from cut petioles by chelating agents. Plant Physiol. 53:96-103.

Klein, 1. and S.A. Weinbaum. 1985. Foliar application of urea to almond and olive: Leaf retention and kinetics of uptake. J. Plant Nutr. 8:117129.

Larcher, W. 1975. Physiological plant ecology. Springer-Verlag, New York. p. 111-113.

Levi, E. 1970. Penetration, retention and transport of foliar applied single salts of $\mathrm{Na}, \mathrm{K}, \mathrm{Rb}$, and Cs. Physiol. Plant. 23:811-819.

Loneragan, J. F., K. Snowball, and A.D. Robson. 1976. Remobilization of nutrients and its significance in plant nutrition, p. 463469. In: I.F. Wardlaw and J.B. Passioura (eds.). Transport and transfer processes in plants. Academic, New York.

Neumann, P.M. 1988. Agrochemicals: Plant physiological and agricultural perspectives, p. 1-13. In: P.M. Neumann (cd.). Plant growth and leaf-applied chemicals. CRC Press, Boca Raton, Fla.

Oertli, J.J. 1968. Extracellular salt accumulation, a possible mechanism of salt injury in plants. Agrochimica 12:461-469.

Oertli, J.J. and W.F. Richardson. 1970. The mechanism of boron immobility in plants. Physiol. Plant. 23:108-116.

Oertli, J.J. and E. Grgurevic. 1975. Effect of $\mathrm{pH}$ on the absorption of boron by excised barley roots. Agron. J. 67:278-280.

Paiva, M. and J. Janick. 1980. Relationship between leaf pubescence and resistance to European red mite in apple. HortScience 15:5 11-5 12.

Pate, J.S. 1975. Exchange of solutes between phloem and xylem and circulation in the whole plant, p. 451473. In: M.H. Zimmerman and J.A. Milbum (eds.). Transport in plants. I. Phloem transport. Encyclopedia of plant physiology. new series. vol. 1. Springer-Verlag, New York. Picchioni, G.A., S. Miyamoto, and J.B. Storey. 1991. Boron uptake and effects on growth and carbohydrate partitioning of pistachio seedlings. J. Amer. Soc. Hort. Sci. 116:706-711.

Plourde, D.F., H.F. Goonewardene, and W.F. Kwolek. 1985. Pubescence as a factor in codling moth, oviposition, and fruit entry in five apple selections. HortScience 20:82-84.

Raven, J.A. 1980. Short- and long-distance transport of boric acid in plants. New Phytol. 84:231-249.

Snedecor, G.W. and W.G. Cochran. 1989. Statistical methods. Iowa State Univ. Press, Ames. p. 390-392.

Swietlik, D. and M. Faust. 1984. Foliar nutrition of fruit crops. Hort. Rev. 6:287-355.

Tukey, H.B. 1952. The uptake of nutrients by leaves and branches of fruit trees. Rpt. 13th Intl. Hort. Congr., London. 1:297-306.

Van Goor, B.J. 1971. The effect of frequent spraying with calcium nitrate 
solutions on the mineral composition and the occurrence of bitter pit of the apple Cox's Orange Pippin. J. Hort. Sci. 46:347-364.

Van Goor, B.J. and P. Van Lune. 1980. Redistribution of potassium, boron, iron, magnesium and calcium in apple trees by an indirect method. Physiol. Plant. 48:21-26.

Weinbaum, S.A. 1988. Foliar nutrition of fruit trees, p. 81-100. In: P.M. Newmann (cd.). Plant growth and leaf-applied chemicals. CRC press, Boca Raton, Fla.

Wittwer, S.H. and F.G. Teubner. 1959. Foliar absorption of mineral nutrients. Annu. Rev. Plant Physiol. 10:13-32.

Wittwer, S. H., W.H. Jyung, Y. Yamada, M.J. Bukovac, R. De, S. Kannan, H.P. Rasmussen, and S.N. Haile Mariam. 1965. Pathways and mechanisms for foliar absorption of mineral nutrients as revealed by radioisotopes. Proc. Symp. Use of Isotopes and Radiation in Soil-Plant Nutr. Studies. Intl. Atomic Energy Agency. p. 387-403.

Wolf, B. 1971. The determination of boron in soil extracts, plant materials, composts, manures, water and nutrient solutions. Commun. Soil Sci. Plant Anal. 2:363-374. 